\title{
LETTERS
}

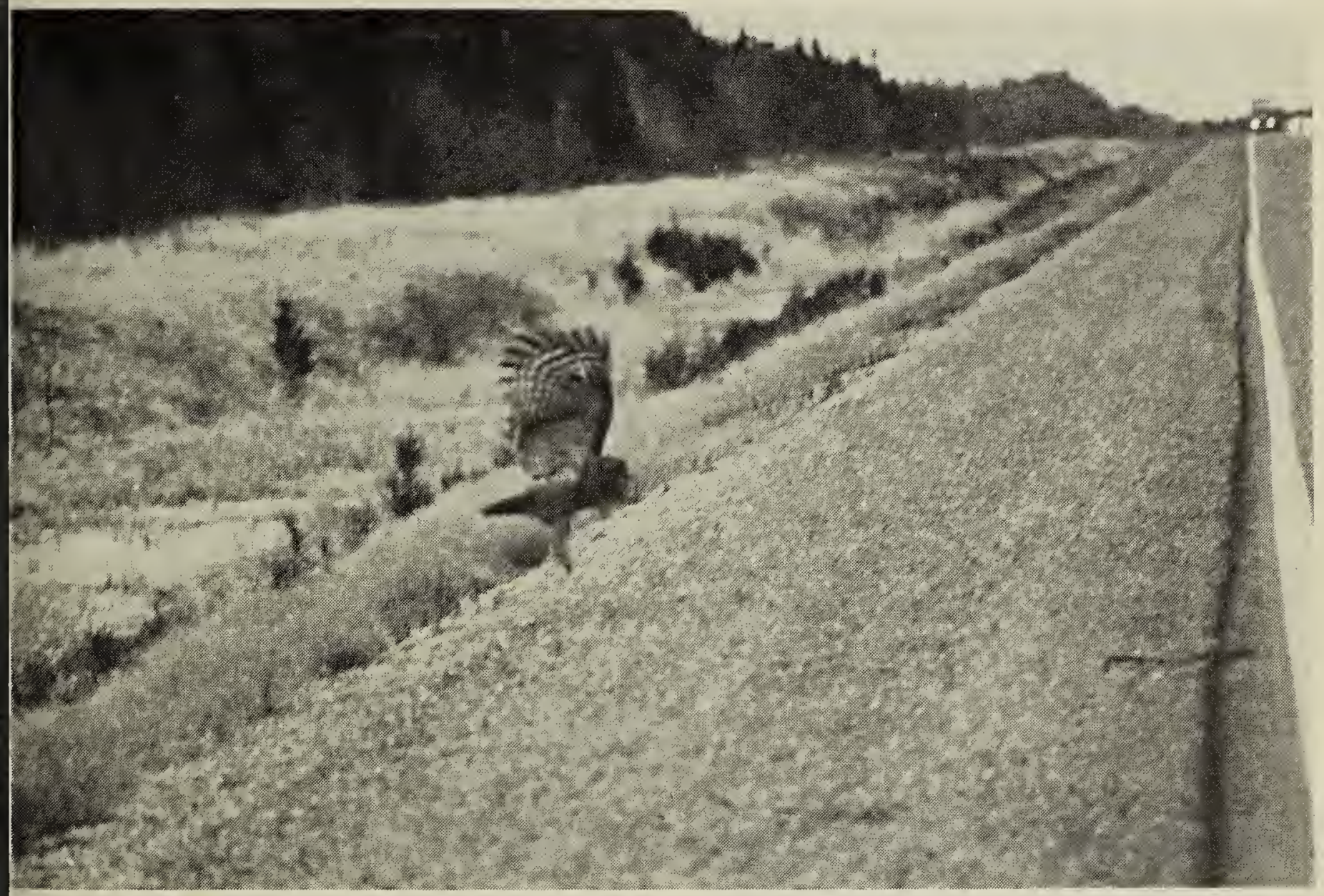

Great Gray Owl.

Eric Feilberg

\section{GREAT GRAY OWL}

This photograph was taken in late March on the west bound TransCanada Highway near East Braintree, Manitoba, which is located in southeastern Manitoba.

The owls can often be seen on the shoulder of the highway. As they fly up they can easily be hit by traffic. They seem to be unable to comprehend the danger so we have to watch out for them. - Eric Haakon Feilberg, East Braintree, Manitoba. ROE OLO

\section{BAT, RACCOON AND BRANT OBSERVATIONS}

I am enclosing some observations which would be interesting to nature enthusiasts.

While I was opening fields in early August, a bat flew out of one of my field shelterbelts and flew in a zig zag fashion to the shelterbelt on the other side of the field some $90 \mathrm{~m}$ away. When it was about half way, I noticed a Kestrel coming toward it in pursuit; when the bat was 
some $6 \mathrm{~m}$ from the trees and $6 \mathrm{~m}$ above them and the little falcon somewhat the same distance from the bat but closing in fast, the bat with a sudden burst of speed dove straight into the trees, changing its erratic flight abruptly. The falcon too, dove among the trees but came out on the other side with no prey. I did not see the bat again. This was approximately 4 o'clock in the afternoon. This I believe would show that bats use their power of sight more than we realize.

On the night of 2 October 1981 a raccoon was killed on Highway 4 some $21 \mathrm{~km}$ north of Swift Current.

On 3 October 1981 while observing flocks of Canada, White-fronted and Snow Geese passing from feeding grounds on sw 20-20-16-W3 over nw 17-20-16-W3 the adjoining quarter, to Lake Diefenbaker I saw a Brant and as it was very dark, almost black, I would say a Black Brant. I was directly under this flock and I would estimate their height at $30 \mathrm{~m}$; I also had binoculars. - Sig Jordheim, White Bear, Sask. SOL 3LO

\section{SCARLET TANAGER AT TURTLE LAKE}

Late in the afternoon of 6 June 1981, I was doing one of my sporadic bird counts of species and nests on the east side of Turtle Lake where I have my summer home. I had recorded 94 species and 7 nests along the $4 \mathrm{~km}$ of shoreline nearest my home and was returning home when a "flash of red" landed in a thicket in front of me. The bird was in a stand of willow, dogwood and birch about $5 \mathrm{~m}$ away from me.

A small patch of yellowish feathers was visible on the left side of the bird's breast. I immediately recognized it as a male Scarlet Tanager. It stayed in the thicket for about 5 minutes after which I ran home excitedly to tell my husband about my find.

The following morning 1 heard a robin-like song just outside of my door and looked out to see the same bird yellow patch and all - on a spruce tree about $15 \mathrm{~m}$ away. I grabbed binoculars and hurried my house-guests Ruth Hicks and Peter Edwards from Edmonton to observe the bird with me. Several other birders on Indian Point (the peninsula where I live) also observed the tanager that day. The following weekend when we returned it had departed. I believe this to be a sight record for Saskatchewan - being 110 $\mathrm{km}$ north of North Battleford in boreal forest. (Weather $+19^{\circ}$ and clear). Muriel Carlson, 406 Spruce Drive, Saskatoon, Saskatchewan. S7N 2N4

\section{OBSERVATIONS AT PELICAN POINT}

Pelican Point is situated on the bend of Last Mountain Lake opposite the mouth of the Arm River.

During the last 14 years we have observed some of the species described by R. D. Symon's book "Hours and the Birds" and we have watched the bucks with velvet antlers stride between the stands of aspen, the flights of pelicans that patrol the lake and the long $V$ 's of geese who fly over the center of the lake in the fall.

Over the years we have made a number of observations of mammals which may be worth recording. Recently, we heard the squeals of a shrew and discovered that it was being swallowed by a garter snake. The cries went on for some minutes. The snake was about two feet long and when it had completely swallowed the shrew it slid off to cover. 
The last two years there was much chittering under the cottage and on occasions an adult Raccoon would climb onto the cottage roof and peer down at us through the picture window. At dusk the adult Raccoon was seen with three kits going down to raid the neighbour's vegetable patch and their tracks could be seen upon the beach where they had been drinking. We have observed Raccoon tracks for the last 10 years, though it was in May, 1960 we first came upon a Raccoon at Kenosee. The Raccoon under our cottage was observed carrying a kit in its teeth by the scruff of the neck in a similar manner to a domestic cat carrying a kitten.

In the early 1970's I saw an otter on a number of occasions at Pelican Point. A neighbour who was standing on a boat jetty watched it swim towards him and roll over exposing its belly. We presumed that it came from the Arm River which is opposite.

A weasel was found in our cottage shed and subsequently seen in the wood pile and among the boat docks. It was chestnut brown and moved swiftly.

The sandy spit called Pelican Point protrudes out into the lake and deer tracks are occasionally found, although it is almost entirely surrounded by cottages. A neighbour observed deer leaving the point and swimming to the opposite shore of Last Mountain Lake a mile away.

There have been a number of reports of Lynx being seen in the area recently. There have been a number of Cougar reports on the Arm River and area around Craven and Valeport.

The hill opposite our cottage contained Badger holes. The Badgers were trapped out subsequently, though in the summer of 1979 we saw a Badger near Last Mountain House and another a week later near Snowasis. Both observations were in the early evening. Tom White, 2580 Retallack Street, Regina, Saskatchewan. S4T 2L4.

\section{WHITE-FLOWERED}

\section{FIREWEED}

There is a good-sized patch of whiteflowered Fireweed on the Indian Reserve at Lake Ministikwa, Saskatchewan, near the highway and north of the lake. My son John Allan, home address Neilburg, maintains Hwy. 21 and saw it from his grader cab, though it is not visible from a car.

He showed the patch to Tom McRae and Elmer Boehr, Dept. of Tourism and Renewable Resources. Any of these three could show the site to a naturalist, if one is interested.

John took me to see the white flowers August 3 last. Flowering was close to finished. The plants seemed slightly more slender than ordinary Fireweed, and the leaves paler green. I believe they were also smoother. - Viola Allan, Box 152, Battleford, Sask. SOM OEO

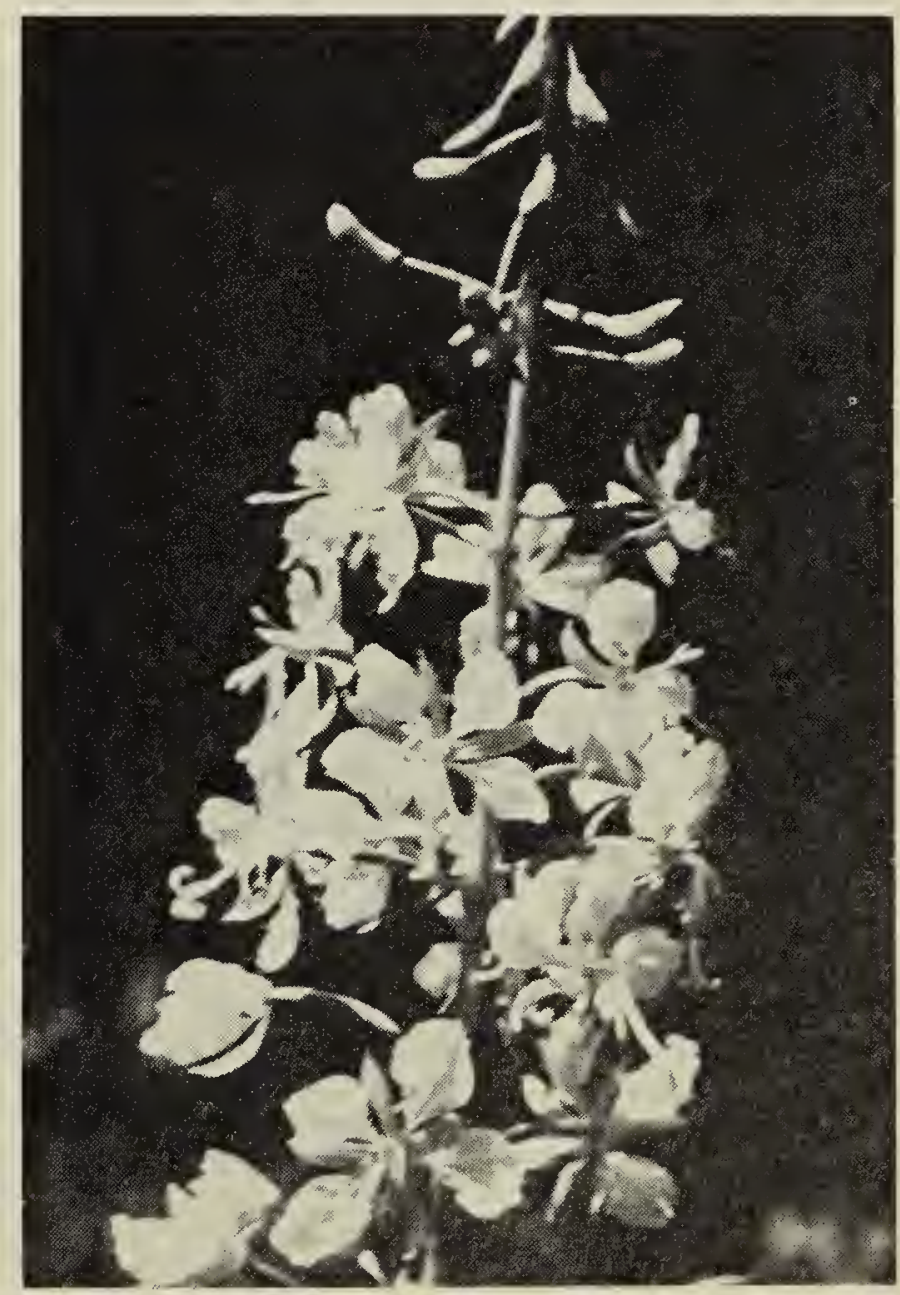

White Fireweed.

Kathy Morck 


\section{INFORMATION WANTED ON WASPS NESTS}

I am gathering information on the large paper wasps' nests that we find now and then in the fall of the year.

I would appreciate receiving specimens of nests from your readers. There are several species of wasps involved. The nests may be different.

Photographs would also be appreciated.

My plan is to resolve some of the following problems:

1. How far north do wasps make nests in Manitoba and Saskatchewan?

2. Do different species of wasps make recognizably different kinds of nests?

3. Wasps will use dry local material and build it into their nests. Pink toilet paper makes strange looking nests! How frequent is this?

4. Personal experiences with wasps would also be appreciated.

5. What happens to nests in the fall? None are found in the spring out in the wilds.
6. Do wasps recycle dead nests?

- Walter Krivda, P.O. Box 864, The Pas, Manitoba. R9A $1 \mathrm{~K} 8$

\section{KESTREL PURSUES BAT}

In July, 1975, near Columbia Lake, British Columbia, at midday, I observed an unusual encounter between an American Kestrel and a bat.

I did not observe the onset of the encounter so can only speculate how it began. When I first caught sight of the pair, the Kestrel was pursuing the bat about thirty feet above the ground. The Kestrel repeatedly dove at the bat; the bat swerved successfully each time. The Kestrel's attacks came from all directions, yet the bat seemed to have chosen an Icarian direction of escape, determinedly climbing upward.

I observed the pursuit for about four minutes, after which the pair had drifted to the east and, vertically, was almost out of sight. - Virginia Lang Young, R.R. No. 1, Busby, Alberta. TOG OHO

\section{CALENDARS \& WEEKLY DIARIES}

\section{ORDER NOW!}

CANADIAN NATURE 1982 Wall Calendar, 24 pp., 12 dramatically beautiful colour photos, 131/4" $\times 11^{1 / 4 "}$;

CANADIAN WILDFLOWERS 1982 Weekly Engagement Diary, 128 pp., 53 colour photos, 5" $\times 8$ ". This popular weekly appointment book now contains photos and information on 20 edible plants, in addition to the stunning photos of wildflowers. Boxed.

Price of Calendar or Diary - $\$ 6.95$ ea. SNHS members deduct $10 \%=$ $\$ 6.25$; Sask. SNHS members add $5 \%$ Tax $=\$ 6.56$. (NOTE: there is no bird diary this year.)

PLEASE ORDER EARLY — THESE QUICKLY GO OUT OF PRINT 